\title{
CHAPTER 56
}

\author{
ROCK MOVEMENT IN IARGE-SCALE TESTS OF RIPRAP STABILITY UNDER \\ WAVE ACTION \\ Thorndike Saville, Jr. \\ U.S. Army Coastal Engineering Research Center, Washington, D.C.
}

ABSTRACT

There have been several instances in the past four or five years of damage to the riprap protection of some earth dams and embankments in major reservolrs in the middle western portion of the Unitea states. In particular, in small sections of the embankment of the Snake Creek sub-impounament in the Garrison Reservolr in North Dakota, some riprap was removed by a severe storm in 1964. It was recognized at the time of construction that the riprap protection to be placed on this embankment was considerably lighter than desirable, and was knowingly placed as an experiment to see if lighter graded material might still provide sufficient protection in a reservolr where the water surface elevation changed periodically. High waves can develop over the 32-mile fetch in this area of frequent high wind velocity. Loss of some riprap in this area has led to an investigation of various schemes of upgrading the riprap. As a part of this investigation, tests have been made at the Coastal Engineering Research Center in Washington, D.C. of vartous types of riprap exposed to wave action. Tests have been made at both small and large scale.

As with most wave tank tests of breakwater or embankment structures, the tests must be run as a short series of bursts of waves, followed by periods of calm. This is necessary because when the wave approaches the structure and breaks upon it, a small portion of the wave energy is not absorbed in the breaking process, but is reflected back along the wave tank. Thls reflected wave, upon reaching the wave generator, is re-reflected and travels again down the tank toward the structure. If mechanical generation of waves continues after the wave is re-reflected from the generator, this re-reflected wave adds to the mechantcally generated wave, and gives a higher wave at the structure than is desired for tests. Accordingly, the wave generator must be stopped at the time the wave reflected from the structure has travelled to and reaches the generator. Thus the tests are run in a short burst of perhaps 10 or 15 waves, followed by a period of time sufficlent to allow the tank water level to calm, and then again a burst of 10 or 15 waves. 
During the tests that have been run at the Coastal Englneering Research Cer + ,er, about 20 frames of motion picture film were taken of the riprap surface following each burst of 10 to 15 waves. The resulting films are then essentially a time lapse movie of the rubble movement in the riprap. The films show very clearly the shifting of the rubble upon the face of the riprap structure. Excerpts from these time lapse films form the major portion of thls presentation. It should be remembered that the films are time lapse, and that when one sees apparent motion in a rock it is not actual motion at the time, but merely the fact the the rock was in one position and is now in another position. The film shows the rock before movement, and the rock after movement, but not the actual act of motion Itself.

As will be noted in the films, there is a rather large amount of motion in the rubble, primarily shifting back and forth. This motion is apparent even with very low waves when actual damage or removal of rock does not occur.

Filns will be shown for two rubble covers. Sections of these are shown in Figure 1. The lirst of these, a Klmmswick limestone, is a graded, well-sorted, subangular rock having a median diameter of 120 los. Fifty percent of the stone is in the 9 to 12 -inch (50-120 lb.) cate zory and the other fifty percent in the 12 to 16 -inch (120 to $275 \mathrm{lb}$. ) category. It thus represents a fairly well-sorted graded material. This was placed from an elevation 7 feet below still water level to an elevation 9 feet above stlll water level. At elevations lower than -7 , larger stone was used primarliy to support the Kinmswick stone to this elevation. Stone below -7 was not assumed to oe critical or susceptiole to movement in the tests. The stone was olace over a layer of smaller spalls, which, in turn, was over a bedding layer, with a bank run gravel core below this. The slope of the structure was 1 on 2 . PhIs structure was tested as giving generalizel information on well-sorted rlprap protection for general application. The particular time lapse film shown is for a wave condition of 3.67 seconds, with waves ranging from 2.55 feet to 3.75 feet in height. Considerable motion is observed at the lower wave helghts, with major danaje belng initiated at a height of 3.45 feet, ana severe damage occurin 3 at a helght of 3.75 feet.

The second structure tested involved an overlay of one laver of placed 80-pound tribars over a rounded boulder protection modeling the exlsting riprap protection on the Snake Creek embaniment. These rounded boulders were taken from the Snake Creek area, and represent uxite accurately an approximately 1 to 2 scale of the current protection. They involve stone ranging from $3-1 / 2$ pouncs to 190 oounàs, with a median size of about 9 Inches (meảian weight of about -7 pounds). One methoa of adaing to the protection Is to upgrade the present riprap protection by placing an overlay of larger rock or some type of concrete mubble shape. Other posslbilities are groutinz of the boulders and using a mesh cover to hold the boulders in place 
during severe wave action. One of the several overlays being tested is a one-layer placed tribar cover, the tribars weighing 80 pounds. This is the one shown in the time lapse pictures.

The wave conditions for the pictures are again a 3.67-second period, with heights ranging from 2.55 to 4.35 feet. Once again considerable movement and shifting of the tribars is seen even at the low wave heights; damage is initiated at a height of 4.05 feet, with severe damage occurring at the height of 4.35 feet.

Another interesting factor shown in the pictures is that frequently when a stone is plucked out or otherwise removed from a place in the stmucture, leaving a damage hole, stone or rubble near to it tend to move into this hole and reheal the damaged section.

Additional tests are being run on other types of riprap, but it was felt worthwhile to show these pictures now and to give an indlcation of the type of movement which occurs in a riprap structure exposed to heavy wave action.

The two sections are shown in photographs 1 and 2 for the limestone, and 3 and 4 for the tribars. Photos 1 and 3 show the sections before wave action was started, and photos 2 and 4 show them after damage has occurred. 


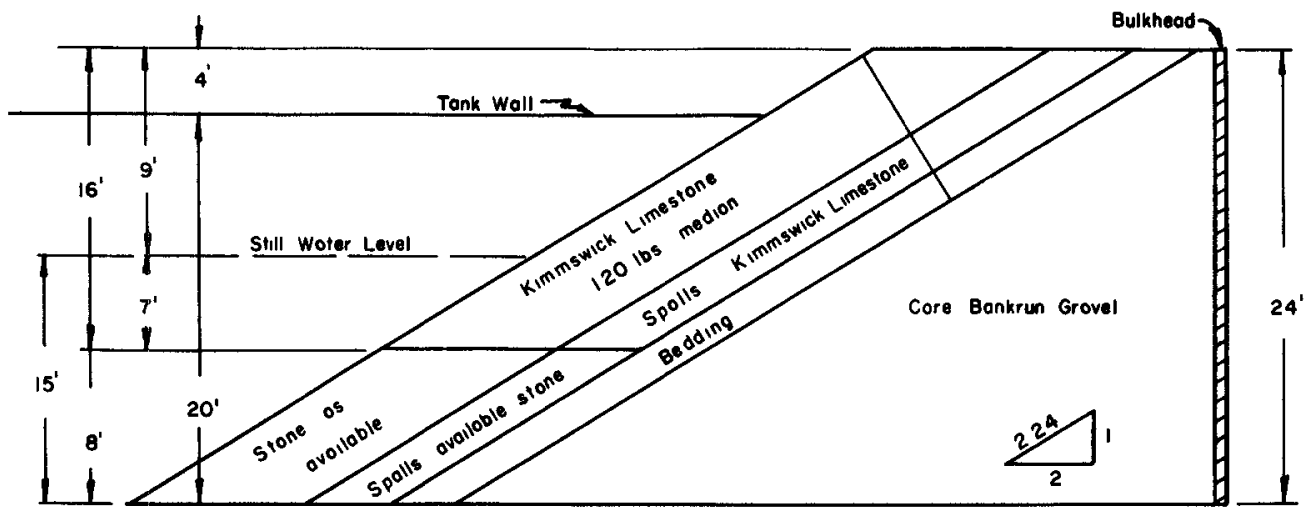

KIMMSWICK LIMESTONE

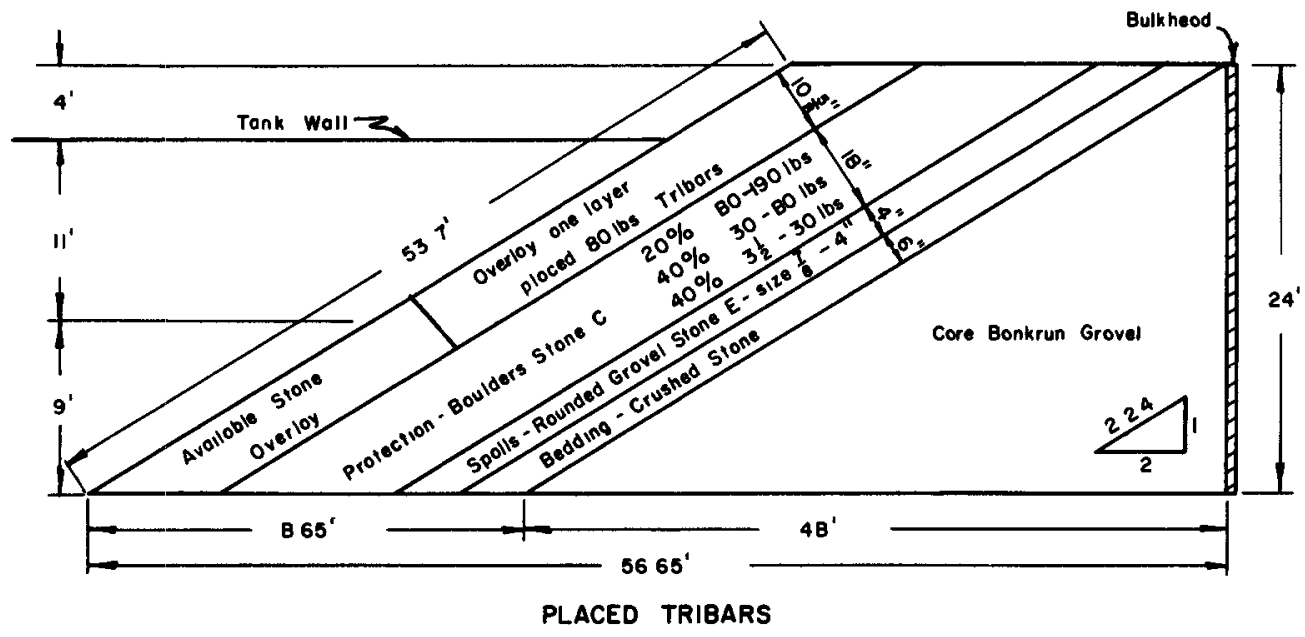

Fig. 1. Test sections for rip rap protection. 


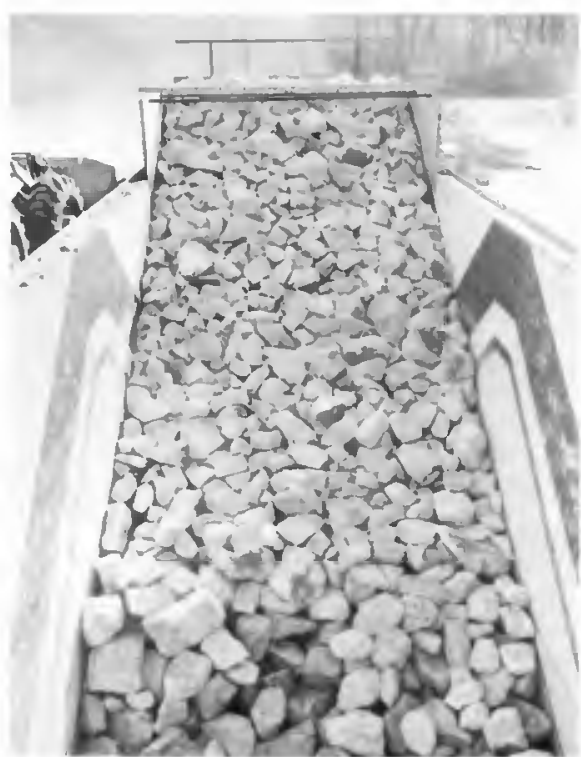

Photo 1

Limestone before waves.

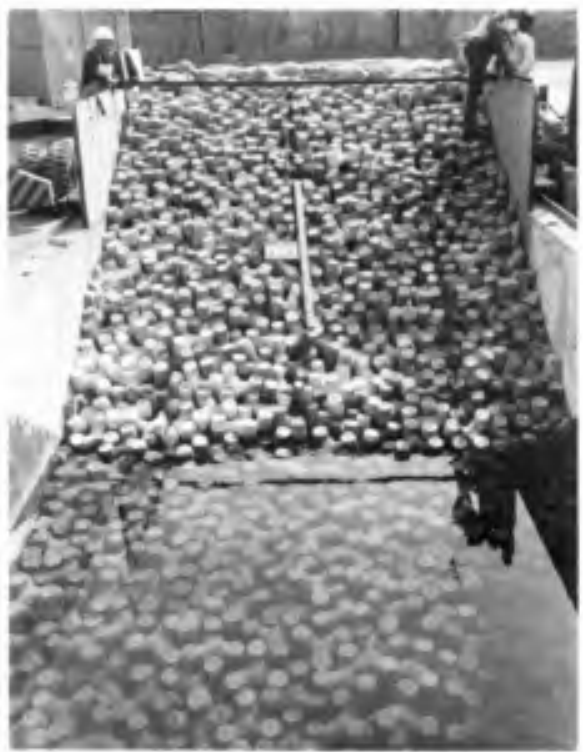

Photo 3

Tribars before waves.

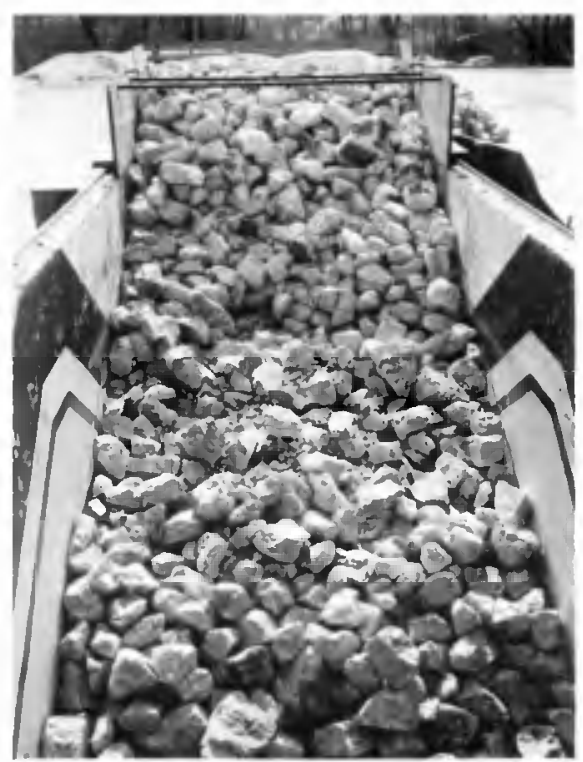

Photo 2

Limestone after waves.

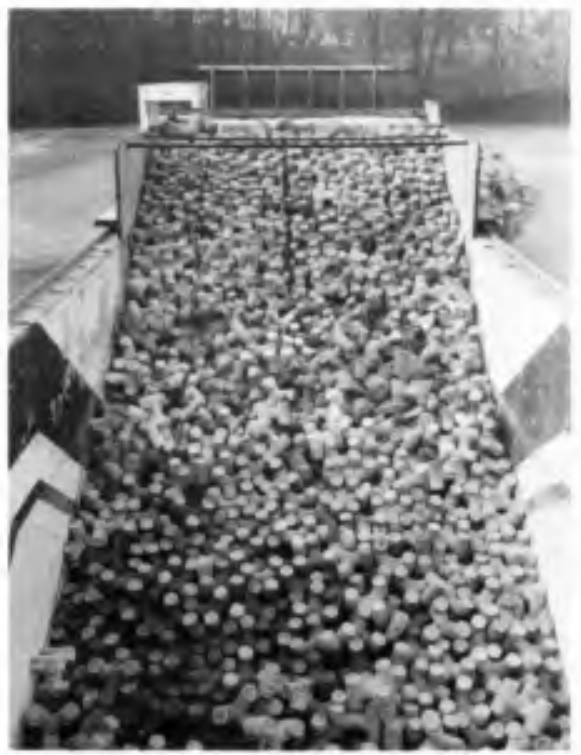

Photo 4

Tribars after waves. 